\title{
Encouraging the Establishment of Legal Clinics in Broadening Access to Justice for the Poor
}

\author{
E Ratnaningsih and E Herawati \\ Faculty of Humanities, Universitas Bina Nusantara, Jakarta, Indonesia
}

ernarn@binus.ac.id

\begin{abstract}
The right to legal aid is one of human rights that guarantee all persons entitled to lawful protection without discrimination. Compare with the limited number of Advocates with the justice seeker, the Law No. 16 of 2011 on Legal Aid extending the subject of legal aid ie. lecturers and law students. It is supposed to help in realizing the wider access to justice for the poor. It conducted to find how good practices for the establishment and the development of legal clinic according to the Law No. 16 of 2011 and how the empowerment of legal clinic will be broadening access to justice for the poor and their sustainable development. This paper is normative legal research using the qualitative approach, and the data were obtained with interview and observation. The results show that there are 5 (five) important aspects must be accomplished in the establishment of legal clinic ie. the foundation of institutional establishment, human resources, clinical law curriculum and learning system, supporting facilities and funding, implementation of legal aid. Another result shows the goal of peace, justice and strong institutions in the SDGs could be achieved by creating affordable and timely access to justice institutions and legal aid services. The results of this study are expected to encourage faculty of law in Indonesia to establish and develop legal clinics and it will meet the need of the poor to get access to justice in rural area.
\end{abstract}

Keywords: Clinic, Legal, Justice

\section{INTRODUCTION}

The right to legal aid is a part of human rights. It is stated in Article 7 of the UDHR which guarantees equality before the law and also provided in Article 16 and Article 26 of The International Conventions on Civil and Political Rights. This rule basically guarantees that all persons are entitled to get legal protection and shall be free from any discrimination including the right on the property. As Lord Birmingham stated that the laws of the land should apply equally to all and must afford adequate protection of human rights [1] and according to Dicey, everyone have have equal positions in the same way [2]. In Indonesia's Constitution, the right to legal aid is not specifically regulate, but it can be derived from the right of recognition, guarantees, protection and certainty before a just law, and the equal treatment before the law (Article $28 \mathrm{D}$ of the 1945 Constitution). Therefore in the legal process, individual's economic disability does not impede a person's right to legal aid. States should regulate that the access for the poor to justice can be obtained through the enactment of the law. 
The law in practice tends to be discriminatory. The law often sits with the one who owns the capital. It is applied consistently to marginal communities, but not to those who have dominant posistion [3]. In criminal cases, not every poor person who is threatened with crime can receive free legal aid. The requirements in obtaining legal aid which is financed by the State are for any suspect or defendant either capable or poor. According to The Indonesia Criminal Procedural Law (KUHAP) the one who will be offered free legal aid is the person who under threat of capital punishment or the threat of 15 (fifteen) years imprisonment. When the examination is still in the stage of investigation, the police will appoint the lawyer for the suspect if he or she commits a crime with a threat over 5 (five) years and poor. When the case examination has been entered in prosecution process, the attorney will appoint the lawyer. When the case already entered the examination in the court, the judge who handles the case will appoint the lawyer. The fulfillment of legal aid right in the Law on Legal Aid is expected to make the bargaining position of the community before the law are stronger.

From the consideration of The Law No. 16 of 2011 on Legal Aid (The Law on Legal Aid), it is a significant to provide widespread legal services to the poor throughout Indonesia. According to Article 9 letter (a) legal aid providers have the right to conduct recruitment of advocates, paralegals, lecturers and students of law faculty. With this legal basis, law faculties throughout Indonesia can establish LKBH or legal clinics to serve the community for access to legal aid and justice. Article 9 of The Law on Legal Aid stated that the types of services can be provided by legal aid organizations including LKBH or legal clinic. These Institutions not only provide legal aid services, but also legal counseling, legal counsultant and other activities related to the legal aid. In 2013, there are 310 organizations have passed the requirements as the legal aid providers by the National Legal Development Board (BPHN). These legal aid providers consist of 208 Legal Aid Institutions including $50 \mathrm{LKBH}$ (Legal Advisory and Consulting Institutions) campuses and 102 community organizations [4].

Constitutional Court Decision (MK) No. 006/PUU-II/2004 reinforces the importance of the role of legal clinic in implementing the third function of Tri Dharma Perguruan Tinggi (Three Pillars of Higher Education) through community service. This decision confirms the importance of legal aid education in the context of the legal education curriculum and its implementors. It means that the legal clinic cannot be separated with the curriculum and the method of learning in legal education. This is what clinical legal education meant [5]. Clinical legal education is described as experimental learning and learning based on practice. Students who take Clinical Law Education will understand what the lawyer will face in doing their job [6]. The importance of the presence of LKBH or the legal clinic in campus is for the fulfilment of public access to obtain justice as guaranteed in the constitution. Therefore, the problems of this research are: 1) to find the existence of LKBH or legal clinic, especially those which are established after the the Law of Legal Aid enacted; 2) To find the best practices of the establishment of LKBH or legal clinic in the universities in Indonesia; 3) the empowerment of legal clinic will be broadening access to justice for the poor and their sustainable development

\section{METHOD}

This research was conducted with qualitative approach. Some empirical data were obtained by interviewing the head and staffs of Legal Clinic or Legal Advisory and Consulting Institutions in Law Faculties at University of Indonesia (UI), Padjadjaran University (UNPAD), Parahyangan University (UNPAR) and Pelita Harapan University (UPH). The data were also gained by conducting observation at Legal Clinic and Legal Advisory and 
Consulting Institutions in each university. From the interviewed data, this research can obtain the description obout the interpretation of the Law on Legal Aid, the experiences of the experts, how the institutions are run, and how the institution were established.

\section{RESULTS and DISCUSSION}

\subsection{Legal Aid in the Constitution, Legislation and Constitutional Court Verdict}

Comparing the legal aid for the poor to get access to justice often relate to pro bono legal service. Helena Whalen-Bridge stated that defining about pro bono is still debatable. Her comparation about pro bono told that in the U.S. pro bono was historically characterised as a charitable act and primarily means civil legal aid. In fact, the constitutional of U.S. guarantees and require the government to fund criminal legal aid and not to civil legal aid. She cited from American Bar Association report on lawyer pro bono, that lawyers reported providing $85 \%$ of pro bono services in civil matters and $15 \%$ in criminal matters. From her research of comparating the legal aid, she concluded that, pro bono has shifted from a charitable conception to a professional obligation. Legal aid is not only on lawyer's obligation either civil or criminal legal aid, but also the State has the obligation to provide indigent representation [7]. Another research conducted by Vermeesch [8] showed that the poor households often discourage to settle their conflict in court, eventhough they can use free legal aid. There are three major reasons why poverty-stricken households would have been discouraged from turning to law courts to settle disputes. First, they may not have owned adequate possessions to trigger disputes. Second, the complexity and lack of transparency of legal procedures to consider judicial action. Third, there could be a sociocultural gap between they who had access to the law which was daunting for lower social groups. Lasky and Nazeri, one of the clinical legal education is to provide "back up" legal services and other services for indigent and marginalized community members who may not have an alternative access to the legal and other support systems [9].

In Indonesia, the aims of the Law on Legal Aid are for: a). Guarantee and fulfill the right of legal aid recipients to have access to justice, b). Realizing the constitutional rights of all citizens in accordance with the principle of equality before the law, c). Ensure the certainty of the implementation of legal aid is carried out equally throughout Indonesia, d). Realizing an effective, efficient and accountable judiciary. The number of poor society usually located in rural area and spread in all Indonesia territory. Therefore, the presence of legal clinics, LBH or LKBH in campus across Indonesia will expand access of Indonesian people to get legal aid services. Beside the Article 9 on The Legal Aid, the involve of lecturers and studets also state in the Decision of the Constitutional Court Number 88/PUU-X/2012 that lecturers and students have important roles in providing legal assistance to the poor community. In its legal considerations, the Court said that the Law on Legal Aid explains and expands the parties that can provide legal assistance. Not only lawyers can provide legal aid, but also paralegals, law faculty lecturers and students, including students from sharia faculty, military and police colleges who are recruited as legal aid providers. (Article 9 letter a of the Legal Aid Law and its elucidation). According to the Court, the service of providing legal aid by lecturers and students of law faculty is an action that must be realized because it is part of the implementation of the third function of Tri Dharma Perguruan Tinggi which is dedicated to the community. In dealing with the cases, paralegals, lecturers and students of law faculty are subject to the same procedural law. Therefore, the Court said that paralegals, lecturers and students of law faculty have the same rights as advocates to provide legal assistance to poor 
citizens. Thus, LKBH and Legal Clinic have the right to recruit lecturers and students of law faculty to provide legal aid for poor society. Furthermore, the law officers and advocates must also recognize and accept the presence of lecturers and students in carrying out their duties to provide legal aid without questioning the licences as an advocate.

\subsection{The best practices of establishment LKBH or Legal Clinic in The Universities in Indonesia}

Wilson stated there are ten practical steps to organize and operate the clinic, i.e: 1) Decide the goals or objectives of the clinical component of legal education witihin general scheme of legal education; 2) Identify apropriately trained personnel to be dedicated to the clinic; 3) Select the subject matter area(s) in which the clinic will practice; 4) Select a time periode for student enrollment in clinic and the appropriate academic credit to be awarded for clinic participation; 5) Devised a system for effective student evaluation or grading; 6) Have a system in place to recruit both students and cases to the clinic; 7) Establish a budget and reliable financial sources for the clinic; 8) Build new and ongoing relationship in the legal clinic community outside of the law school; 9) The legal clinic must be able to manage its cases as a law firm within a alw school; 10) Design a practical seminar to be offered in conjunction with clinic casework [10].

Law school curriculum have its difficulty because the legal course for law students often concentrated on traditional lawyering and corporate law practice. It is important to give attention to school programs to enable students how to learn the attitude of sensitivity and concern for the legal needs of those who hardly afford the services of a lawyer. Further, there is too much law for those who can afford it and too little for those who cannot. If only a system would be devised so that law schools can be given major participation in the enlightenment of their student's population to encourage a sense of purpose and mission to ensure that even marginalized groups are provided an opportunity to be given an effective legal assistance [11].

Based on the definition of legal clinics presented by The Indonesian Legal Resource Center (ILRC), the clinical legal education is defined as a learning process with the intention of providing law students with practical knowledge, skills, values to implement legal services and social justice through interactive and reflective teaching methods. Thus, the development of legal clinics within the university is intended to develop an understanding for students to have soft skills and experiences in applying the theory in the University. However, based on the results of research in several law campuses in Jakarta, Bandung and Tangerang shows that establishing an institution such as a legal clinic and legal aid in the university is not easy. Factors to be considered are complex, including legal aspects of the establishment, organizational structure, human resources, cooperation development, program development and adherence to the curriculum, availability of facilities and most importantly funding.

The legal clinic means an organization under a university or law faculty that provides legal aid services to poor communities. The presence of legal clinics is needed by the community to get legal aid in solving the legal problems of the poor. On the other hand, the existence of legal clinics is also as the manifestation of Tri Dharma Perguruan Tinggi that is community service. With the presence of legal clinics, the lecturers not only teach about law theories but also the legitimate skills obtained from field practice in cooperation with partner institutions. However, to establish a legal clinic is difficult so it should require the standart for the establistment legal clinic as follows: 
Table 1. The Standard Aspects for Establishing the Legal Clinic.

\begin{tabular}{|c|c|c|}
\hline No & Standard & Description \\
\hline 1. & $\begin{array}{l}\text { Decision Letter } \\
\text { of Establishment }\end{array}$ & $\begin{array}{l}\text { The Basis of establishment and organizational structure: } \\
\text { Organization Structure from Rector Decree and from Dean of } \\
\text { Faculty of Law decree. }\end{array}$ \\
\hline 2. & $\begin{array}{l}\text { Curriculum Legal } \\
\text { Clinic }\end{array}$ & $\begin{array}{l}\text { Curriculum Development al: Clinic of criminal, civil, anti- } \\
\text { corruption law, business law, etc. }\end{array}$ \\
\hline 3. & $\begin{array}{l}\text { Human } \\
\text { Resources }\end{array}$ & $\begin{array}{l}\text { Development of student screening/selection system Based on } \\
\text { study program specification } 3 \text { Human Resources: } \\
\text { - Lecturers and practitioners } \\
\text { - Administration staff } \\
\text { - Cooperation with Mastering in practice }\end{array}$ \\
\hline 4. & Facilities & $\begin{array}{l}\text { Classrooms with facilities: } \\
\text { - Meeting room } \\
\text { - Consultation Room } \\
\text { - Destruction Can be adjusted to the availability of existing } \\
\text { facilities on campus }\end{array}$ \\
\hline 5. & Funding & $\begin{array}{l}\text { - Funds from university or study program budget } \\
\text { - Cooperation with other agencies: is usually not in the form of } \\
\text { funding but the provision of facilities. }\end{array}$ \\
\hline
\end{tabular}

Sources: concluded from research interview, observation and legal clinic documents

Refer to the table above, first aspect is the organizational structure of legal aid. Decision Letter (SK) establishment of the legal clinic can be from Rector's Decission or Dean Faculty of Law. When the legal clinic established under the Dean of the Faculty of Law, the legal clinic program is supported by the budget from the Faculty of Law. These two forms of legitimate legal clinic establishment need to be based on the organizational structure of the University, concerned and the formation of legal clinics is selected so that the legal clinic can effectively perform its functions and receive funding support from the university. At the faculty level, LKBH have the functions as a laboratory, to improve faculty accreditation and the clinical legal curriculum.

Legal Clinic can be part of PPKH (Training Education and Legal Proficiency) with 2 (two) credits and emphasis on practice in the field. The methods used were face-to-face meetings (30\%), in-house or ex-house legal practices (65\%) and evaluation (5\%). In implementing this legal practice, legal clinics can work with partners such as Police, Attorney, Courts, NonGovernmental Organizations, Penitentiaries, Law Offices and others. When the form of legal institution is $\mathrm{LBH}$, the activities are not directly related to the teaching curriculum but more to the final assignment of student apprenticeship. Related to Human Resources, the fourth university's legal clinic personnel consist of lecturers, students and staffs. The commitment and capacity of lecturers to manage the legal clinics is the great importance, especially the availability of their time because it will conduct student monitoring during the apprenticeship process at partner institutions or monitor the handling of cases in LBH campus. Students will be engaged through the selection process and interviews to ensure they can attend activities in legal clinics such as having social awareness to the poor, having skills in procedural matters, having the ability to work with work teams and others. The selection process is done because these students will represent the law faculty in the partner institution. The staffs recruited and hired by legal clinics to help lecturers to manage legitimate clinics. The need of supporting 
facilities can be the part of the law faculty building or separated. The rooms need such as living room, administration room, faculty room, study room, discussion room and meeting room. The Funding of legal clinics or LBH comes from university's budget or can obtain funds from BPHN due to constrained requirements of lawyers are bounded. Lecturers and staff managing legal clinics are supplied by the faculty/university. While mentors from partner institutions is not provided with salary or honorarium because they invited as a speaker or guest lecturer in the law faculty.

Based on the mapping of the implementation of legal clinics or LBH Campus at four universities, there can be formulated the best practices of legal clinic as a guidance for law faculty that want to establish a legal clinic, as follows:

1) Laying the legal clinic's position and structure into a strategic unit or institution under a law or university faculty that receives financial support and facilities from a law or university faculty. The existence of the legal clinic is a part of Tri Dharma Perguruan Tinggi program especially for community service and preparing students to develop legal skills that can be a provision when they work as law practicioner;

2) The legal clinic is the part of the course in the law faculty and the legal proficiency training education to give more emphasis on legal practice in the field. Law clinic lecturers upgrade module (curriculum) subject of legal clinics in accordance with the needs of faculty such as clinical curriculum of criminal law, civil, women and children, anti-corruption and others. The material taught in legal clinics is different from the courses of training in legal proficiency and procedural law. To support this method, the legal clinic works with partners who act as mentors from students. The mentor also provides an assessment of the students;

3) Availability, management, development and strengthening of human resources. The lecturers must have high commitment and responsibility in managing legal clinic to provide legal learning in legal clinics. They also monitors the evolution of apprentices in partner institutions. Students who follow the subject of legal clinics have the obligation to follow certain requirements and tests that have passed the law course of the event;

4) Facilities and availability of funds should play as an important element for the establishment of a legal clinic. The availability of the room or building facilities and the funds determine the success of the objectives of the establishment of legal clinics. Legal clinics or LBH Campus must have rooms that function to conduct the lclinical activities. Program financing and faculty salaries and administrative staff are financed by law faculties or universities or the legal clinic or LBH Campus can develop funding sources from research programs involving lecturers and students.

\subsection{The Establishment of Legal Aid in order to broaden access to justice for the Poor and Their Sustainable Development}

Access to justice is the latest approach in development cooperation. This focus supports and is supported by the human rights approach to development. Access to justice is a fundamental right and the key way to defend other rights. The human rights approach provides the necessary framework of action for human development. [12] Access to justice can be obtained if people in suburban/rural areas get legal assistance from legal aid institutions including legal clinics. By encouraging the establishment of a legal clinic in the Faculty of Law in the provinces and/or districts, it will expand the reach of access to justice for the poor. 
A meaningful "Bill of Rights" for rural poor in the Third World can only be derived from and through the struggle of people to confront the kinds of conditions which contributes significantly to their impoverishment and repression and which presently frustrate their opportunities for development [13]. For this reason, the poor need helps from a legal clinic to empower themselves to fight for their rights contained in the constitution through legal assistance in resolving their legal problems.

The empowerment of justice and fundamental rights of people and certainty of law could have played an integrating role in the whole development precepts and results of deeply thought discussions in long series of meetings during the last decades. Thus, the problem of human rights has to be reviewed on the basis of the contextual structure of developments of the society. Legal assistances for the grassroots accordingly, therefore must be conducted considerably to accommodate a transforming-force structure of the society [14]. Structural legal assistance requirements structural change, changes in social order; from an unfair order to a just order where social, economic, political, legal and cultural resources are returned to the majority of the people [15]. So, the role of legal clinic to provide legal aid is not only accompany the poor in litigation but also in non-litigation including empowering the poor trough training and discussion in the community.

In most country in Asia, legal aid has been developing uniquely Asian approach to legal aid which link legal aid intimately with both justice and development [13]. It is also stated in the Sustainable Development Goal 16 is peace, justice and strong institutions which promote peaceful and inclusive societies for sustainable development, provide access to justice for all and build effective, accountable and inclusive institutions at all levels. Peaceful, just and inclusive society is necessary to achieve SDGs. People everywhere need to be free of fear from all of violence. It is important that government, civil society and communities work together to implement lasting solutions to reduce violence, deliver justice, combat corruption and ensure inclusive participation at all times [16].

Provide access to justice for all in the SDGs is important agenda in order to promote peaceful and inclusive societies for sustainable development. Access to justice will obtain if the huge number of legal clinics take part to provide free legal aid for the poor and empower their ability to develop and defend their rights. Policy briefing from Institute of Development Studies states if the SDGs are to achieve their aim of establishing a safe, sustainable and just society for all, the post-2015 framework should place security, justice and inequality at the centre of a global pursuit for sustainable development. Progress towards this could be achieved by establishing an objective that enables citizens to hold states accountable by securing rights to land and property for men and women, ensuring citizen participation in monitoring the effective provision of essential services such as healthcare, water and education and creating affordable and timely access to justice institutions and legal aid services [17] The government and University should support the establishment of legal clinic to take part in SDGs goal to create legal aid services for the poor through supporting facilities and funds to run their activities.

\section{CONCLUSION}

The Indonesian Constitution regulates the right to guarantee and certainty of the same legal law and equal treatment as stipulated in article $28 \mathrm{D}$ of The Constitution of Republik Indonesia 1945. The enactment of The Law No. 16 of 2011 show the commitment of The Government to regulate the provision of legal aid and its budget. This Law also extends the legal aid providers who are not only advocates but also paralegals, lecturers and students of 
law faculty. The role of the lecturers and students in the provision of legal aid for disadvantaged communities is also reinforced by the decision of the Constitutional Court Number 88/PUU-X/2012 that the provision of legal assistance services by lecturers and students is an action that must be realized because it is the implementation of the third function From Tri Dharma Perguruan Tinggi especially for community service. The implementation of legal clinical research in Law Faculties showed that to establish a legal clinic or LBH Campus requires a high commitment from lecturers who will give legal clinic courses either from curriculum or clinical module Law and student monitoring at partner institutions. It also requires the interest and willingness of high students to have empathy for the poor and help to resolve their legal problems. The role of the faculty or university is needed to support the room or building facilities and funding for operational activities of legal clinics including salaries or honorarium lecturers of legal clinics and administrative staff as well as interest from law faculty students to serve. Best practices to establish a legal clinic or LBH campus is not easy. Aspects that must be adequately prepared include the legal establishment, organizational structure, human resources, development of legal clinics programs and the suitability of the curriculum, the availability of facilities and funding. It requires a very high level of commitment both for lecturers who will be able to teach law clinics, faculty leaders and universities that will provide space or building support and funding for the implementation of legal clinics. To choose the form of legal clinic or LBH campus, the policy-makers on campus should consider three main issues when establishing legal clinics: legal clinic position or status or LBH campus, human resources available and funding as well as curriculum or module of law clinic course. These are needed to provide the best legal service for the poor as it stated in the goals of sustainable development.

\section{ACKNOWLEDGEMENTS}

This research was supported by Bina Nusantara University Grant in 2016

\section{REFERENCES}

[1] C. Harlow and R. Rawlings, Law and Administration. Cambridge University Press, 2009.

[2] A. W. M. and A. V Dicey, "Introduction to the Study of the Law of the Constitution," Columbia Law Rev., vol. 15, no. 7, p. 644, Nov. 1915.

[3] R. Surbakti, Demokrasi dan Nomokrasi Problematika Hukum dan Peradilan di Indonesia (Komisi Yudisial Republik Indonesia). Jakarta: Komisi Yudisial Republik Indonesia, 2014.

[4] U. P. Sihombing, S. Aminah, M. K. Roziqin, and A. Wahid, Pendidikan Hukum Klinis (Clinical Legal Education) dalam Pelaksanaan UU No. 10 Tahun 2011 tentang Bantuan Hukum. Jakarta: The Indonesian Legal Resource Center, 2014.

[5] A. M. Fultoni, S. Aminah, and U. P. Sihombing, Mengelola Legal Clinic: Panduan Membentuk dan Mengembangkan LBH Kampus untuk Memperkuat Akses Keadilan. Jakarta: The Indonesian Legal Resource Center, 2009.

[6] Open Society Justice Initiative, Pendidikan Hukum Klinik Tinjauan Umum. Jakarta: The Indonesian Legal Resource Center (ILRC), 2013.

[7] H. Whalen-Bridge, "The Conceptualisation of Pro Bono in Singapore," Asian J. Comp. Law, vol. 9, pp. 97-143, Jan. 2014.

[8] G. Vermeesch, "Access to Justice: Legal Aid to the Poor at Civil Law Courts in the 
Eighteenth-Century Low Countries," Law Hist. Rev., vol. 32, no. 3, pp. 683-714, Aug. 2014.

[9] B. Lasky and N. M. Nazeri, "The Development and Expansion of University-Based Community/Clinical Legal Education Programs in Malaysia: Means, Methods, Strategies,” Int. J. Clin. Leg. Educ., vol. 15, p. 59, Jul. 2014.

[10] G. Vermeesch, "Access to Justice: Legal Aid to the Poor at Civil Law Courts in the Eighteenth-Century Low Countries," Law Hist. Rev., vol. 32, no. 3, pp. 683-714, Aug. 2014.

[11] A. S. Valera, R. P. Ledesma, and J. F. Plantilla, The Need for An Integrated Approach in Providing Legal Services to the Rural and Marginalized Sectors of the Philiphine Society Legal Aid in Developing Countries. Jakarta: The Indonesian Legal Aid Foundation, 1990.

[12] UNDP, Penyusunan Program untuk Keadilan: Akses bagi Semua Orang, Sebuah Pedoman bagi Praktisi mengenai Pendekatan Akses terhadap Keadilan berbasis Hak Asasi Manusia. Bangkok: UNDP, 2005.

[13] D. Clarence, Human Rights and Legal Resources for Development Legal Aid in Developing Countries. Jakarta: The Indonesian Legal Aid Foundation, 1990.

[14] P. S. Baut, Introduction Legal Aid in Developing Countries. Jakarta: The Indonesian Legal Aid Foundation, 1990.

[15] LBH Jakarta, Bantuan Hukum di Wilayah Konflik, Pembelajaran tentang Konflik dan Konsep Bantuan Hukum Struktural. Jakarta: LBH Jakarta, 2015.

[16] United Nations, "Peace, Justice and Strong Institutions: Why They Matter," United Nations, 2017. [Online]. Available: https://www.un.org/sustainabledevelopment/wpcontent/uploads/2017/01/16-

00055p_Why_it_Matters_Goal16_Peace_new_text_Oct26.pdf.

[17] IDS, "Sustainable Development Goals Must Consider Security, Justice and Inequality to Achieve Social Justice," The Institute of Development Studies, 2015. [Online]. Available: https://www.ids.ac.uk/publications/sustainable-development-goals-mustconsider-security-justice-and-inequality-to-achieve-social-justice/. 